\title{
MAPOVÁNÍ BEZBARIÉROVOSTI PĚŠÍCH TRAS Z PASPORTU゚ A DTM
}

\author{
Jiří HORÁK ${ }^{1}$, Lucie ORLÍKOVÁ ${ }^{1}$, Pavel KUKULIAČ ${ }^{1}$, Renata ZDAŘILOVÁ2 \\ ${ }^{1}$ Katedra geoinformatiky, Hornicko-geologická fakulta, Vysoká škola báňská - Technická univerzita Ostrava, \\ 17. listopadu 15, 70833 Ostrava, Česká republika \\ ${ }^{2}$ Katedra městského stavitelství, Fakulta stavební, Vysoká škola báňská - Technická univerzita Ostrava, 17. \\ listopadu 15, 70833 Ostrava, Česká republika \\ ¡iri.horak@vsb.cz, lucie.orlikova@vsb.cz, pavel.kukuliac@vsb.cz, renata.zdarilova@vsb.cz
}

doi: https://doi.org/10.31490/9788024845081-103

\begin{abstract}
Abstrakt
Na základě podrobné rešerše českých zákonů, norem, doporučení, metodik, vyhlášek a technických podmínek Ministerstva dopravy byly popsány požadavky na parametry pěších komunikací zejména z pohledu potřeb osob se zdravotními omezeními. Následně byla provedena formalizace těchto kritérí a jejich transformace do datové struktury, která umožňuje prověřovat splnění kritérií v GIS a tedy i zmapovat situaci ve vybraném území. Současně z rešerše vznikla i doporučení, které parametry je potřebné měřit a evidovat, aby bylo možné provádět vyhodnocování bezbariérovosti tras a poskytovat rady, která místa a které situace zlepšovat $s$ cílem zlepšování situace $v$ bezbariérovosti ve městě. Pro centrum Ostravy byl proveden průzkum datových zdrojů k detailnímu popisu místních komunikací a škále technických objektů, městského mobiliáře a vegetace, které mohou ovlivňovat podmínky průchodnosti po místních komunikacích. $\mathrm{Na}$ základě vybraných kritérií byla provedena úvodní analýza bezbariérovosti pěších tras $v$ centrální části Ostravy na základě dostupných údajů z pasportů místních komunikací a DTM.
\end{abstract}

\section{Abstract}

Mapping of barier-free conditions of pedestrian paths from Digital Technical Maps: Requirements on the parameters of pedestrian paths, namely from the point of view of persons with health disabilities, are described from the legal conditions on the base of detail review of Czech laws, norms, recommendation, methodology, regulations and technical conditions of the Ministry of Transport. Sequentially, these criteria were formalized and transformed into data structure which enable to check and verify fulfilling of these criteria in GIS, thus to map all barriers in the selected area. At the same time corresponding recommendations were created. Such way it is possible to discover what places in what situation should be improved to be more inclusive, senior-friendly and barrier-free. The review of data source for detail mapping of streets, pathways, as well as various surrounding natural and technical objects (incl. street furniture) was performed for the centre of Ostrava. The initial analysis of bariers on pedestrian paths using the developed set of criteria and available data from local communications and DTM was conducted as a first step in more detail mapping and analysis.

\section{Klíčová slova: bezbariérovost; chodník; chodec; DTM; pasport}

\section{Keywords: barrier-free; pavement; pedestrian; Digital Technical Map}

\section{1. ÚVOD}

Městské prostředí nabízí řadu príležitostí pro fyzickou mobilitu, díky které mají obyvatelé města dostupnou širokou škálu pracovních, obchodních i volnočasových aktivit ( $v$ době mimo pandemii). Městské prostředí však vytváři také řadu nástrah a potíží, se kterými se člověk během mobility musí vyrovnávat. Většina lidí aktivního věku a dobré zdravotní kondice tyto problémy ani nevnímá, avšak pokud je člověk třeba dočasně omezen v pohyblivosti (např. dočasné zdravotní potiže, doprovázení osoby s takovým omezením, pohyb $s$ kočárkem či vozičkem atd.), zjištuje, že bezbariérovost v prostředí měst není zcela běžná ani jednoduchá. Řada měst aktivně pracuje na odstraňování bariér a zlepšování dostupnosti pro osoby $s$ určitým omezením. Významně v tom pomáhají také neziskové organizace a jednotlivci, kteří provádějí mapování bezbariérovosti chodníků, veřejné dopravy a budov a reálně prověřuji možnosti a omezení v praxi a upozorňují orgány města (resp. jejich technické služby) na konkrétní problémy a napomáhají tak jejich rychlému odstraňování. 
Vedle těchto iniciativ však máme $v$ ČR vyspělou soustav norem a vyhlášek, které poměrně podrobně na základě dobré znalosti problematiky takových skupin obyvatel jako jsou vozíčkáři a nevidomí, specifikují požadavky na pěší trasy, parkování, zařízení v budovách atd.

Budování smart cities využivá principu digitálních dvojčat (Batty, 2018, Farsi et al., 2020), díky kterému máme v ideálním případě podrobnou digitální reprezentaci městského prostředí. Je tedy možné vyzkoušet, nakolik Ize ověřovat vhodnost jednotlivých tras, míst a objektů $v$ městském prostředí $z$ hlediska kritérií, stanovených $v$ normativních dokumentech či doporučeních. Taková řešení mohou rychle odhalit místa, kde pravděpodobně mohou hendikepované osoby mít problém při své mobilitě a následně tato místa prověrit a případně realizovat nápravná opatření.

V rámci projektu TAČR „Senzorové měření pěších komunikací v městském prostředí pro podporu mobility osob se zdravotními omezeními“ se zabýváme otázkami bezbariérovosti a mapování městského prostředí. Cílem př́spěvku je představit některé možnosti realizace takových analýz.

\section{REŠERŠE POŽADAVKU゚ NA BEZBARIÉROVOST}

Na základě podrobné rešerše českých zákonů, norem, doporučení, metodik, vyhlášek a technických podmínek Ministerstva dopravy byly popsány požadavky na parametry pěších komunikací zejména z pohledu potřeb osob se zdravotními omezeními.

Mezi základní právní předpisy a české technické normy postihující širokou oblast technických požadavků bezbariérového užívání pozemních komunikací a veřejných prostranství patří vyhláška č.398/2009 Sb., o obecných požadavcích zabezpečující bezbariérové užívání staveb, ČSN 736110 Projektování místních komunikací a ČSN 73 6425-1 Autobusové, trolejbusové a tramvajové zastávky, přestupní uzly a stanoviště Část 1: Navrhování zastávek.

Rešerše také zahrnula zahraniční normové prostředí oblasti bezbariérového užívání včetně norem stanovující kritéria rozměrových parametrů prvků hmatových úprav pro nevidomé. $\vee$ této oblasti existuji rozdíly mezi našimi a zahraničními standardy, což Ize doložit např. na srovnání hmatových prvků „varovné vzory“ (tab. 1). V ČR je aplikován jiný pohled na používání hmatových vzorů a tvarové řešení je v návaznosti na požadavky nařizením vlády č.163/2002 Sb., kterým se stanoví technické požadavky na vybrané stavební výrobky (viz přiloha 2, bod 12, Výrobky pro osoby s omezenou schopností pohybu a orientace) a z něj vycházejících technických návodů Technického a zkušebního ústavu stavebního.

Tab. 1 Požadavky na kulovité prvky (kulové úseče) pro varovné hmatové vzory dle různých norem

\begin{tabular}{|l|c|c|c|}
\hline & Průměr základny, $\mathrm{mm}$ & Výška komolého kužele, $\mathrm{mm}$ & Rozteč, $\mathrm{mm}$ \\
\hline ČR & $\mathbf{2 0 - \mathbf { 2 5 }}$ & $\mathbf{4 - \mathbf { 5 , 5 }}$ & $\mathbf{5 0 - 1 0 0}$ \\
\hline ISO 21 542 & $25-35$ & $4-5$ & $45-61$ \\
\hline CEN/TS 15209 & $20-30$ & $5 \pm 1$ (min. 4) & 4 kusy výstupků na $1 \mathrm{dm}^{2}$ \\
\hline
\end{tabular}

Metodika mapování přístupnosti na území České republiky zahrnující výhradně uživatelská hlediska (MMR, pracovní skupina pro jednotnou metodiku mapování a kategorizaci přístupnosti prostředí, SONS, ADNEP). Našim cíle je využít nastavená kritéria pro automatizované vyhodnocování plnění podmínek v místech s DTM a pasporty.

\section{FORMALIZACE KRITÉRIÍ}

Na základě rešerše byly vymezeny základní typy kritérií, jednotlivá kritéria formalizovány jako soustava logických podmínek a uloženy jako soustava parametrů v databázi.

Jako př́klad hlavních kritérií je možno uvést:

- Šířka chodníku + bezpečnostní odstup

- Základní šírka $150 \mathrm{~cm}$, tři typy okolí z hlediska bezpečnostního odstupu:

- Pevné (budovy, zábradlí apod.) $-25 \mathrm{~cm}$

- Dopravní (silnice, cyklostezka apod.) $-50 \mathrm{~cm}$

- Volné (záhon, volné prostranství apod.) $-0 \mathrm{~cm}$ 
- podélný sklon $-8,3 \%$

- maximální délka s podélným sklonem

- odpočívadla s minimální délkou $1,5 \mathrm{~m}$ a sklonem do $2 \%$

- príčný sklon $-2 \%$

- výškové rozdíly - do $2 \mathrm{~cm}$

- neklouzavý povrch dle smykového tření a sklonu

- mezery v roštu - do $2 \mathrm{~cm}$

Tyto hlavní kritéria jsou dále modifikovány $v$ prípadě specifických podmínek (např. cyklostezky, kombinace s tyčovými objekty atd.). Zvláštní podmínky jsou kladeny na taktilní povrchy, přechody, parkoviště, zastávky veřejné dopravy a další objekty.

$\mathrm{K}$ tvorbě datového modelu pro zápis kritérií, stejně jako pro evidenci objektů, bylo využito CASE nástrojů Toad Data Modeller a Enterprise Architect. Zápis kritérií do databáze umožňuje efektivně vyřešit tvorbu jejich kombinací a využít je při automatizované kontrole.

\section{DATOVÉ ZDROJE}

Uplatňování kritérií pochopitelně vyžaduje mít k dispozici adekvátní datové zdroje.

K základní patří DTM obce, jejiž obsah specifikuje vyhláška 233/2010 Sb. o základním obsahu TM obce. $\checkmark$ případě DTM MO je $k$ dispozici i řada bodových objektů (obr. 1), vč. zeleně, dopravních zařízení a různých tyčových objektů.

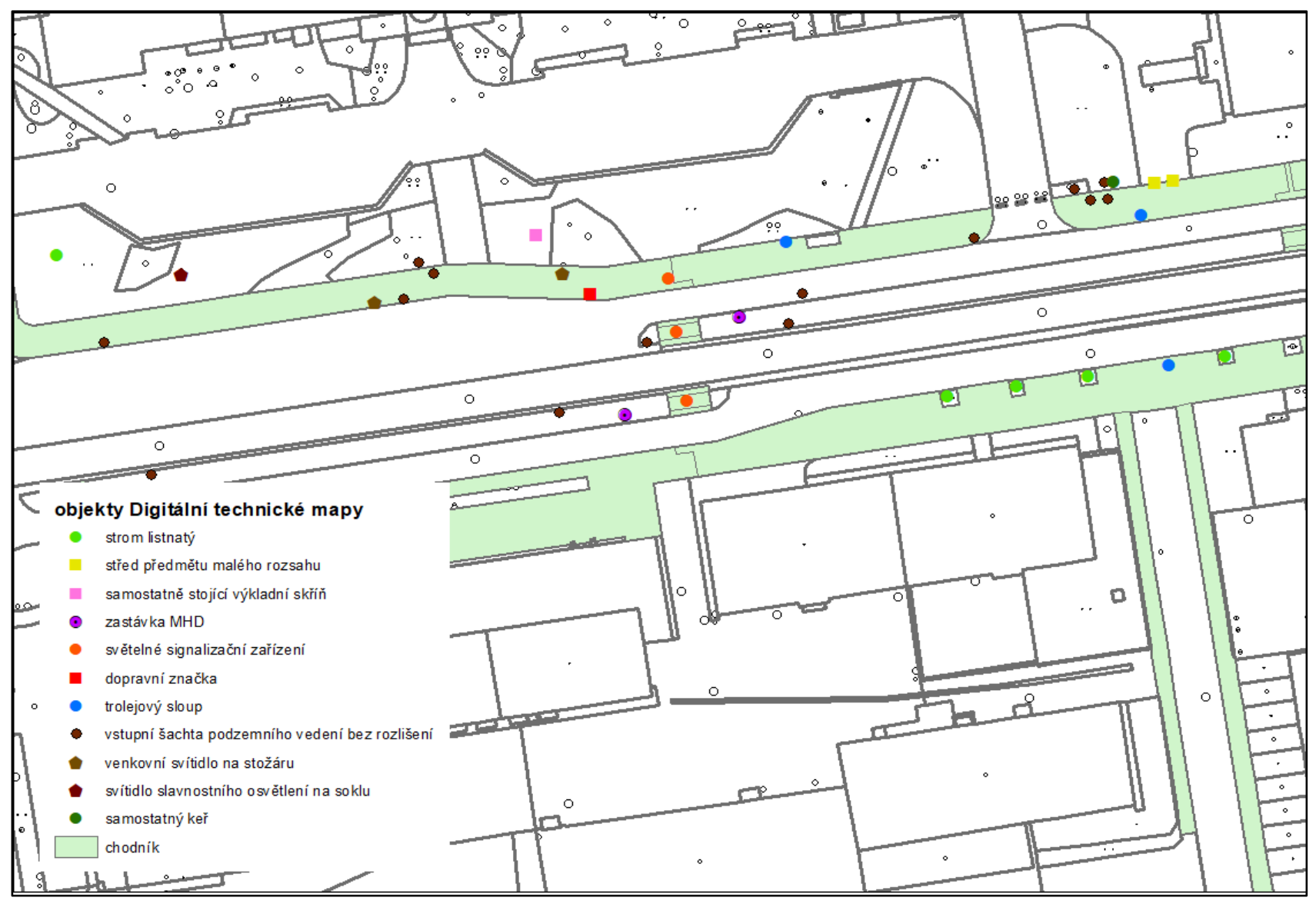

Obr. 1 Ukázka obsahu DTM MO

Z DTM MO se odvozuje pasport místních komunikací, který rozšiřuje potřebné atributy a také provádí segmentaci úseků podle typu povrchu.

Inspirací byly rovněž informace o pasportizace a DTM v jiných městech. Např. v Praze podrobné konstrukční údaje evidované Technickou správou komunikací. V Jihlavě evidence minimální a maximální šiřky jednotlivých úseků, jejich sklon, evidence deformací, výtluků, trhlin, či podrobnosti mobiliáře. V Opavě 
evidence bezbariérových informací a $v$ Přerově detailní evidence obrubníků z hlediska bezbariérovosti a aktuální evidence poruch.

Rovněž byly využity informace z vybraných částí mezinárodních standardů jako je CityGML a IFC pro prvky chodník, rampa, zeleň, květináč apod.

Všechny tyto informace byly podkladem při tvorbě vlastního datového modelu a implementaci databáze.

\section{PROSTOROVÉ ANALÝZY}

Jednou z možností využití formalizovaných kritérí je realizace prostorových analýz, které umožní vyhodnotit míru jejich splnění $v$ městském prostředí $s$ využitím dat digitálních modelů, zejména evidence DTM a jednotlivých pasportů. Jejich cílem je indikace problémových míst.

Jako první kritérium byla hodnocena šiřka chodníku včetně požadovaných odstupů od pevných objektů a dopravních cest. Analýza byla provedena v prostorové databází PostGIS.

Vstupní vrstvy resp. objekty jsou klasifikovány do příslušných tříd, podle kterých se generují odpovídající obalové zóny, reprezentující požadovaný odstup. Následně se provede ořezání segmentů chodníku o tuto obalovou zónu. Pak se provede rozšiření o polovinu kontrolované šiř́ky. Vzniklé polygony představují jádra úseků, kde jsou podmínky šířky a odstupu splněny. Pro lepší identifikaci úseků nesplňujících tato kritéria se provede dilatace „průchodných“ segmentů zpět na celkovou požadovanou šiřku a odečte se původní stav. Ve finále je vhodné ještě začištění (eliminace třísek a prachu z nedokonalých překryvů).

Výsledek pro vybrané části centra Ostravy je na obr.2.

Výsledky ukazují, že problém dostatečné šiřky chodníků (vč. požadovaných odstupů) je v centru města poměrně běžný, i když vezmeme v potaz úroveň přesnosti měření při tvorbě DTM a pasportizaci (obr. 3).

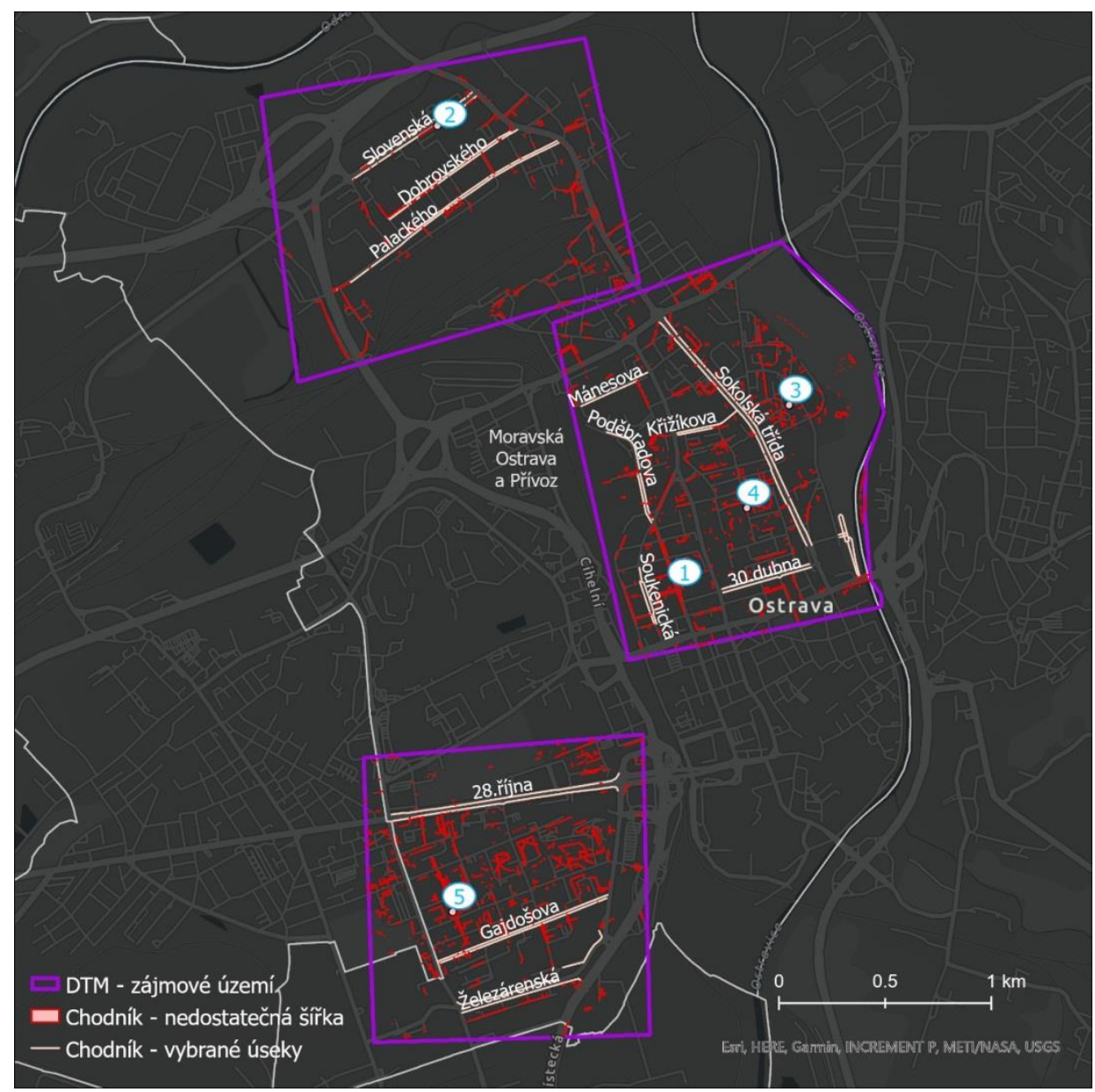

Obr. 2 Vyhodnocení plnění kritéria šířka chodníku a odstupy na vybraných místech v centru Ostravy 


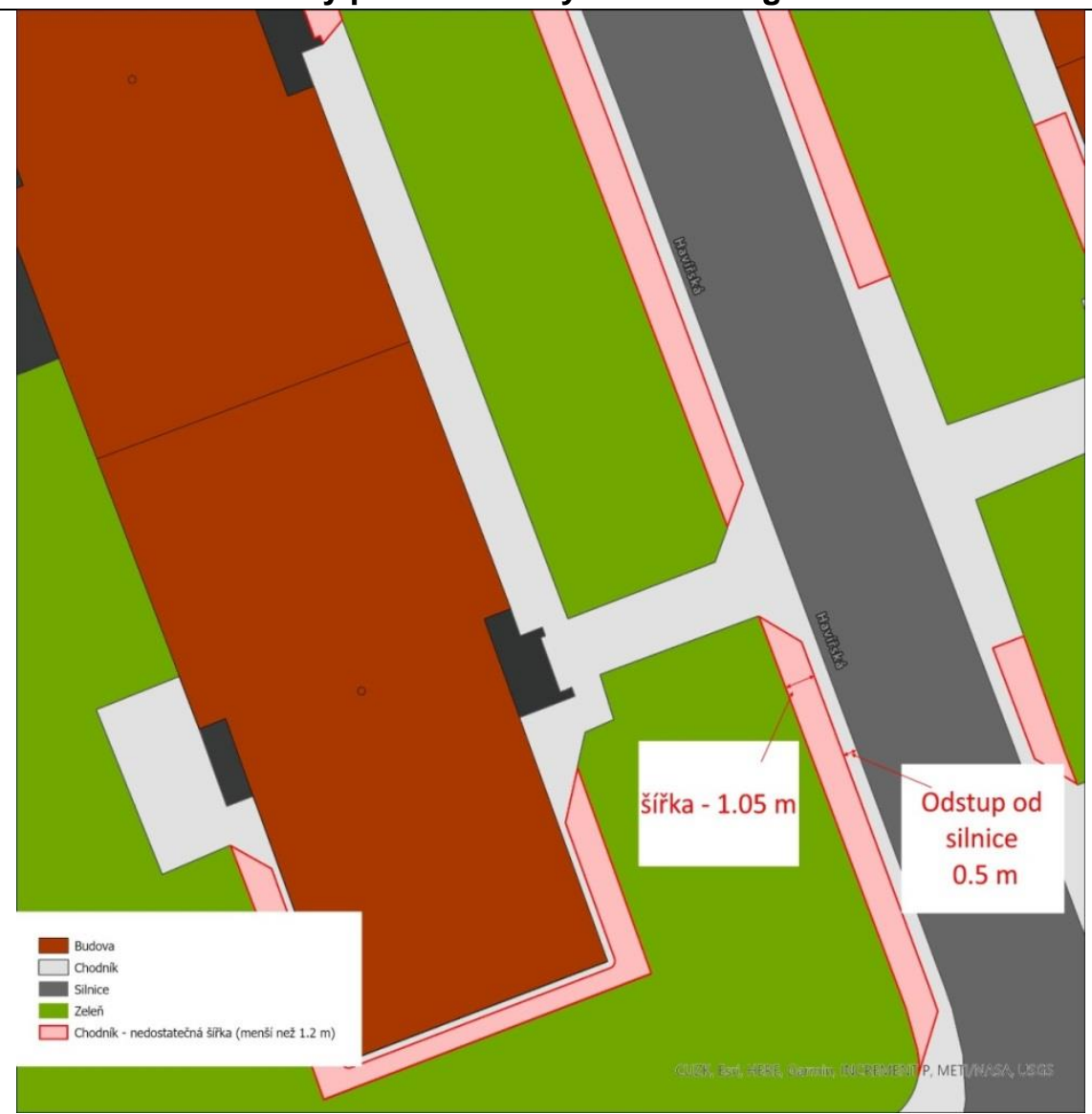

Obr. 3 Detail hodnocení šírky chodníků a odstupů na ul. Haviřská.

\section{ZÁVĚR}

Budování smart cities $s$ využitím principu digitálních dvojčat umožňuje začít realizovat i poměrně detailní prostorové analýzy městského prostředí. Jednou z možností je prověření chodníků z hlediska jejich bezbariérovosti pro potřeby lidí na invalidních vozíčcích a nebo osob se zhoršeným viděním. Na základě provedené podrobné rešerše českých zákonů, norem, doporučení, metodik, vyhlášek a technických podmínek Ministerstva dopravy byly identifikovány požadovaná kritéria, která byla následně formalizována a uložena v databázi.

S využitím dat DTM obce a pasportů komunikací, městského mobiliáře a zeleně je možné realizovat prostorové analýzy plnění kritérií.

$\checkmark$ centru Ostravy byla provedena první taková analýza, zaměřená na kritéria šiř́ky a odstupů od objektů. Výsledky ukazují, že $v$ centru měst existuje řada míst, která mají se splněním požadavků potíže.

Do budoucna chceme analýzy postupně rozšiřovat o další kritéria, implementovat zohlednění nepřesnosti měření a provést validační měření a hodnocení v realitě.

\section{LITERATURA}

1. ----- (2002): Nařízení vlády č.163/2002 Sb., kterým se stanoví technické požadavky na vybrané stavební výrobky, ve znění pozdějších předpisů

2. ---- (2006): ČSN 73 6110:2006 Projektování místních komunikací, Změna Z (2010)

3. ---- (2007): ČSN 73 6425-1:2007 Autobusové, trolejbusové a tramvajové zastávky, přestupní uzly a stanoviště - Část 1: Navrhování zastávek

4. ---- (2008): CEN/TS 15209:2008 Tactile paving surface indicators produced from concrete, clay and stone

5. ---- (2009): Vyhláška č. 398/2009 Sb., o obecných technických požadavcích zabezpečujících bezbariérové užívání staveb

6. ---- (2011): ISO 21542:2011 Building construction - Accessibility and usability of the built environment 
7. ---- (2016): Mapování přístupnosti prostředí, MMR 2016, https://www.mmr.cz/getmedia/9052a26bfac0-4adf-aec7-0be6b814b9a5/Mapovani-pristupnosti-prostredi rijen-2016 1.pdf

8. Batty M. (2018): Digital twins.. Environment and Planning B: Urban Analytics and City Science 2018 45:5, 817-820. https://doi.org/10.1177/2399808318796416

9. Farsi M., Daneshkhah A., Hosseinian-Far A., Jahankhani H. Digital twin technologies and smart cities. Springer, 2020. ISBN: 978-3-030-18732-3 